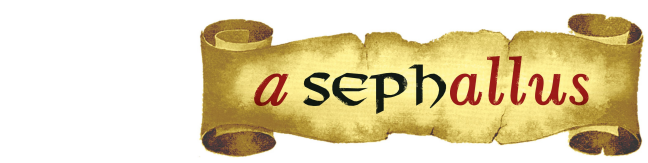

Revista aSEPHallus de Orientação Lacaniana

Núcleo Sephora de Pesquisa sobre o Moderno e o Contemporâneo

ISSN 1809 - 709 X

Ideal viril e feminização do mundo: uma sexuação moebiana na era do não-todo

Vinícius Moreira Lima

Graduando em Psicologia pela UFMG (2015-2019),

Pesquisador na área de psicanálise e teoria queer, Bolsista de iniciação científica PIBIC-CNPq.

E-mail: vmlima6@gmail.com

Ângela Maria Resende Vorcaro (orientadora) Psicanalista, membro da Association Lacanienne Internationale, Doutora em Psicologia Clínica (PUC-SP), Professora do Departamento de Psicologia da FAFICH/UFMG.

E-mail: angelavorcaro@uol.com.br

Resumo: 0 artigo pretende perguntar quais mudanças são acarretadas pelo declínio do ideal viril no nível da sexuação, fazendo o percurso que leva da sociedade pautada no ideal fálico até sua derrocada contemporânea. A falência do viril revela que a sexuação apresenta um caráter moebiano, que situa, de partida, todo ser falante como concernido pelo não-todo fálico. Explicita o modus operandi do ideal viril para lançar luz sobre as proliferações do não-todo no século XXI, em sua rebeldia ao universal. Como conclusão, discute as consequências clínicas possíveis para os horizontes contemporâneos da subjetividade.

Palavras-chave: psicanálise, ideal viril; sexuação; gozo; falo; objeto $a$.

L'idéal viril et féminisation du monde: une sexuation moebienne à l'ère du pas-tout: Cet article a l'intention de discuter quels changements sont causés par le déclin de l'idéal viril au niveau de la sexuation, en faisant le chemin qui conduit de la société basée sur l'idéal phallique jusqu'à son déclin contemporain. La décadence du viril révèle que la sexuation a un caractère moebien, ce qui place tout parlêtre comme concerné par le pas-tout phallique. Le modus operandi de l'idéal viril est expliqué pour éclairer les proliférations du pastout au XXIe siècle, dans sa rébellion à l'universel. En conclusion, des conséquences cliniques possibles pour les horizons contemporains de la subjectivité sont discutés.

Mots clés: psychanalyse; idéal viril; sexuation; jouissance; phallus; objet $a$.

Virile ideal and feminization of the world: a moebian sexuation in the age of the not-all: This article intends to ask about what changes are entailed by the decline of the virile ideal in the process of sexuation, discussing the trajectory from the phallic ideal that governed Occidental society to its contemporary decay. The collapse of the virile reveals that sexuation presents a Moebian character, that situates, from the start, every speaking being as concerned by the not-all phallic. The virile ideal's modus operandi is explained to throw light over the proliferations of the not-all in the $21^{\text {st }}$ century, in its refractoriness to the universal. As a conclusion, some possible clinical consequences for the contemporary horizons of subjectivity are discussed. Key words: psychoanalysis; virile ideal; sexuation; enjoyment; phallus; object $a$. 


\title{
Ideal viril e feminização do mundo: uma sexuação moebiana na era do não-todo ${ }^{1}$
}

\author{
Vinícius Moreira Lima \& Ângela Maria Resende Vorcaro
}

\section{Introdução}

Como sabemos, o surgimento da psicanálise é contemporâneo dos primeiros indícios de uma série de mutações sociais no cenário ocidental, transformações da ordem de um declínio do pai e da falência de certo ideal viril (Lacan, 1938/2003a). Foi ainda no princípio dessas modificações que Freud realizou suas observações clínicas, seguido de perto por Lacan, que pôde avançar suas formulações no decorrer do século XX. No entanto, esse conjunto de alterações, agora no século XXI, ainda está por ser esquadrinhado de forma mais precisa. Nosso trabalho se insere, portanto, no esforço de localizar as implicações dessas mudanças para a sexuação no contemporâneo, na esteira de autores como Miller (2010), Fuentes (2012), Sinatra (2013) e Santiago (2013).

Nessa direção, temos o objetivo de elucidar, inicialmente, aquilo que constitui o ideal viril tradicional, para, em seguida, localizar sua decadência no contemporâneo. Tentaremos explicitar a forma como a subjetivação moderna buscava se pautar em um regime todo fálico, no que o ser e o ter o falo estariam, ambos, todo subsumidos pela lógica fálica. Em seguida, pensaremos o avanço teórico de Lacan com as fórmulas da sexuação como decorrente da urgência de tornar mais complexa uma leitura sobre o gozo, derivada da insuficiência relativa dos operadores ser e ter para dar conta da sexualidade do ser falante. Depois, discutiremos o que implica, no nível da sexuação, a desconstrução do imaginário dos gêneros tradicionais. Assim, poderemos lançar luz sobre as proliferações contemporâneas do não-todo, para pensar possíveis consequências clínicas de postular uma sexuação moebiana nos termos de suas articulações com o falo, o S( ) e o objeto a em um processo analítico em homens.

\section{O ideal viril e a norma fálica}

Dentro da psicanálise lacaniana, parece haver relativo consenso em definir o contemporâneo na linha proposta por Miller (2010) e continuada por Sinatra (2013) e Santiago (2013) como dizendo respeito a um declínio do pai como operador hegemônico da subjetividade, seguido de uma queda do viril, com a decorrência de uma feminização do mundo. Inicialmente, vamos nos deter na questão do ideal viril, por considerá-la a pedra angular para localizar o crescimento das manifestações do não-todo no século XXI, ponto central que ainda resta ser suficientemente elaborado. Para isso, partiremos de uma retomada das formulações de Lacan a respeito do falo na década de 50, concentradas no seu texto de 1958 sobre o tema ("A significação do falo"), mas à luz do que se desdobrou posteriormente em sua teoria, a partir de seu axioma de que não existe relação sexual. 
Em "O aturdito", Lacan (1972/2003b) não hesita em situar "na questão central do ser ou ter o falo", "a função que supre a relação sexual" (Lacan, 1972/2003b, p. 457). Isso significa que ser e ter não passam de tentativas de suplência, sempre já marcadas pelo fracasso, à inexistência da relação sexual, isto é, ser ou ter é o que compõe uma solução entre outras para contornar a ausência de uma proporção ou complementaridade entre os sexos. Essa relativização do psicanalista francês sobre esses dois operadores subjetivos possibilita uma reconsideração das colocações lacanianas presentes em seu escrito de 1958, na medida em que, ali, Lacan (1958/1998a) pontua que o falo, como significante, aponta para "as estruturas a que serão submetidas as relações entre os sexos" (Lacan, 1958/1998a, p. 701).

Isso significa, desde o princípio, partir de uma perspectiva que desnaturaliza a relação do sujeito ao sexo, inserindo-o numa articulação discursiva, isto é, a partir de uma posição subjetiva na linguagem frente ao falo. No entanto, nesse momento do ensino de Lacan, as duas posições possíveis ainda estavam todo subsumidas à lógica fálica, no que tanto o ser como o ter o falo estão totalmente reportados ao mesmo significante, sem ter sido ainda elaborado seu mais além. Tal gesto teórico - o de avançar um mais além da castração - só seria possível ao longo de seus seminários posteriores, com destaque para o Seminário 20. Ainda assim, a forma como a teoria se organizava na década de 50 refletia a maneira hegemônica com que o sofrimento neurótico apareceu na clínica ao longo do século XX, girando precisamente em torno dessa questão central do ser e do ter o falo.

Assim, a teoria lacaniana do falo como significante se adequava à realidade da clínica que então se apresentava, em que os sujeitos neuróticos se viam às voltas com uma organização subjetiva que orbitava em torno dos ideais fálicos, servindo a própria teoria como denúncia do malestar subjetivo produzido a partir do ideal, que era, nesse caso, o ideal viril centrado no falo. Essa hipótese ganha força ao observarmos que o efeito do comparecimento do falo na economia psíquica era o de "projetar inteiramente as manifestações ideais ou típicas do comportamento de cada um dos sexos, até o limite do ato da copulação, na comédia" (Lacan, 1958/1998a, p. 701). Isso por meio da intervenção de um parecer, no nível dos semblantes, que, ao velar o nada, substitui o "ter", com a finalidade de "protegê-lo" (Lacan, 1958/1998a, p. 701) do lado dos homens, isto é, de permitir a exibição de uma ostentação ou parada viril (ainda que o órgão nunca esteja à altura da função), e também para "mascarar sua falta" (Lacan, 1958/1998a, p. 701) do lado das mulheres, ao Ihes franquear a possibilidade de colocar em cena sua mascarada.

Lacan (1958/1998a, p. 701) insiste precisamente no caráter de "ideais" que essas duas posições encarnam no discurso, ideais que, a nosso ver, ainda estavam todo orientados para a lógica fálica. Em outros termos, ser e ter eram totalmente absorvidos dentro da lógica do falo. Essas eram as condições para que vigorasse certo ideal viril no terreno da neurose, algo que a construção das tábuas da sexuação (Figura 1) nos ajudaria a elucidar alguns anos depois, com a instalação do neurótico como restrito ao lado dito masculino. Acreditamos que os esforços de 
Lacan para escrever a sexuação derivam da relativa insuficiência lógica e teórico-clínica dos operadores ser/ter o falo para pensar os fenômenos que começavam a aparecer em maior escala em sua época, em decorrência das mutações em questão: declínio do pai como operador hegemônico da subjetividade, queda do viril, feminização do mundo.



Figura 1 - Tábuas da sexuação

Atento a esse processo histórico, o psicanalista francês trabalhou a lógica dita masculina da sexuação, da ordem do todo fálico, a partir da exceção que funda a regra, com o mito viril que foi sintetizado por Freud em Totem e tabu. Essa lógica de gozo, baseada num universal que se orienta por uma exceção mítica (Lacan, 1971-1972/2012, p. 105), é toda localizada sob a égide do falo, o que tem efeitos para a estruturação subjetiva inconsciente. Isso implica que todo sujeito que se organiza na linguagem a partir dessa lógica está ancorado em um gozo que suspira pelo universal, que busca fazer Um, isto é, Um-niverso (Teixeira, 2007, p. 36). Dessa maneira, todo ser falante que aqui se coloca teria como referência lógica para seu gozo o Pai mítico da horda primitiva, aquele que seria capaz de gozar de todas as mulheres.

Essa função lógica encontra suas representações imaginárias mais comuns em duas ficções. Primeiro, na de um homem que fosse capaz de equiparar-se ao Pai gozador, um homem que gozasse de todas as mulheres devido à sua pretensa posse efetiva do falo. Com isso, por não ser castrado, ele poderia se alçar à posição de exceção que organiza o conjunto todo fálico da sexuação. $E$, segundo, na ficção de ser $A$ mulher (como a Dama do amor cortês), que estaria à altura de captar o amor desse homem, tornando-se, com isso, a exceção que fisga o detentor do falo em relação às outras mulheres, fazendo com que essa mulher seja eleita por esse homem na posição de falo. Assim, trata-se da instituição lógica de duas posições no discurso que davam esteio a dois ideais: para as mulheres, o de ser A mulher que todo homem desejaria e, para os homens, o de ter A mulher que todo homem desejaria. Essa seria a proposta normativa tradicional, em que ser e ter se configuram como pares totalmente subsumidos pela lógica do falo: homens que o têm, mulheres que o são. 
Foi a partir desse ideal viril que os gêneros tradicionais, com a ilusão do binarismo homemmulher, puderam se sedimentar, estruturados a partir dessas duas ficções ancoradas no ideal viril, que é, por definição, falocêntrico. Se, por tantas vezes, a psicanálise foi acusada de falocentrismo, foi precisamente por colocar em evidência que a estruturação dos seres sexuados, tal como se apresentavam à sua clínica, era feita a partir do falo como semblante central (Fuentes, 2012, p. 131). No entanto, desde a época de Freud, já saltava aos olhos a insuficiência desses ideais normativos para dar conta do ser falante no discurso. Essa tentativa de organizar o gozo a partir do ser e do ter se mostrou sempre já como falha, na medida em que há homens que procuram ser o falo e há mulheres que buscam tê-lo, contrariando aquilo que era uma espécie de ideal socialmente partilhado.

Seguindo nessa esteira, podemos articular a hipótese de que o ideal viril que organizava os gêneros tradicionais tentava esgotar o gozo na lógica do todo fálico: ser ou ter. Ao longo da modernidade, o imaginário dos semblantes de gênero, em sua roupagem binária, heterossexual, tentou recobrir a desordem estrutural no real, correlata de um gozo que não se submete totalmente à norma fálica. Foi a guinada teórica de Lacan (1972-1973/2008b) em direção a esse Outro gozo que nos permitiu depreender o caráter localizado e restrito da lógica fálica para prestar contas do ser sexuado; afinal, a lógica dita feminina da sexuação, o não-todo fálico, é aquela que faz objeção ao universal, denunciando as tentativas do conjunto masculino de formar uma totalidade fálica.

Se o não-todo faz furo no semblante fálico, desmascarando-o em suas pretensões de esgotar o gozo dentro da lógica do falo, isso implica objetar às tentativas de enquadramento do gozo nos arranjos dos gêneros tradicionais, no que o gozo, sempre singular, é rebelde à universalização. Essa leitura da lógica da sexuação nos permite observar o fracasso do empreendimento tradicional dos gêneros, tomados como a tentativa de formar classes universais, nas quais reuniríamos sujeitos por partilharem um mesmo atributo, por apresentarem um atributo comum (Lacan, 1971-1972/2012, p. 181). Partindo dessa definição, podemos situar os gêneros tradicionais, os semblantes do masculino e do feminino decorrentes da lógica todo fálica enquanto tentativas de formar duas classes universais: a dos homens e a das mulheres (Lacan, 19711972/2012, p. 95-96). No entanto, o gênero acaba por se revelar, de um lado, como sendo a sedimentação violenta de uma ilusão (o universal masculino) e, de outro, a decepção decorrente de uma desilusão (a inconsistência feminina).

Por parte dos homens, essa esperança da universalidade pareceu levar à sua realização, já que a presença do falo (no imaginário do órgão) Ihes facilitava a ilusão de ter o falo (simbólico), o que formaria o conjunto a partir desse Um-niversal. Por causa disso, a lógica masculina da sexuação apresentaria maior afinidade com os semblantes, algo que a lógica feminina contraria radicalmente. Pois, se do lado masculino a ilusão de ter o falo permite formar o conjunto a partir da crença no semblante, o lado feminino denuncia a verdade desse semblante como insuficiente, 
pelo fato de que a tentativa de fazer um universal d'A mulher se mostra impossível. Isso na medida em que não houve aí um candidato a semblante que se equiparasse ao falo imaginário como elemento organizador, que permitisse a sua reunião num conjunto que faz universo, que é o que se passa no campo do masculino. Como consequência, os homens ficam mais embrutecidos na ilusão fálica, na falsa totalidade, porque o pênis se prestou melhor como referente para o símbolo que franqueia essa reunião, a qual, no limite, por ser uma ficção neurótica, também esbarra no impossível de fazer Um.

Ainda assim, não se trata de cair na ilusão de que esse engodo do Um seria necessariamente desejável, ou mesmo de que as mulheres seriam vistas pela psicanálise em déficit em relação aos homens por não "terem" o falo. Diferentemente, o não-todo tem um interesse privilegiado de um ponto de vista psicanalítico, por ser mais afim à singularidade, descrendo nos semblantes demasiado totalizantes da cultura. Pois não se trata de trocar um ideal por outro, de fazer uma substituição que retorne ao mesmo lugar do Um, de outro ideal que tente fechar o Todo no lugar do falo; a lógica dita feminina tem muito a nos ensinar a esse respeito, uma vez que há uma tendência contemporânea (mas que marca presença desde o feminismo do século XIX) de fazer Um pela via oposta, de tentar elevar, por exemplo, a vagina ao estatuto fálico de um ter que busca fazer universo.

O problema dessa estratégia é manter a lógica fálica em pleno funcionamento, ainda que às avessas, pois desconhece a saída subversiva do não-todo para o mal-estar na civilização. Se, do lado dos homens, o falo é um elemento que, na linguagem, faz função de organizador dos valores do ideal viril, do lado das mulheres, por sua vez, não haveria esse elemento que poderia ser atribuído de forma paritária ao universal do gênero "mulher". Esse elemento não é discernido; a vagina, por vicissitudes históricas que decerto incluem algo da dominação masculina, não foi elevada a um símbolo unificador tal como foi o falo para o lado masculino ${ }^{2}$. Entretanto, disso não segue que deveríamos buscar promover a consistência do conjunto das mulheres em torno da vagina. Afinal, uma crítica histérica ao ideal viril, reivindicando a posse do falo, pode ser feita de uma posição inconsciente ainda muito identificada a esse ideal. 0 que interessa à psicanálise é o fato de que essa crítica pode abrir espaço para um consentimento com o não-todo (Fuentes, 2012, p. 190), para uma possível feminização do sujeito (que não necessariamente irá derivar de uma feminização do mundo), o que acreditamos ser bem demonstrado pelas invenções de Liniker, como discutiremos na próxima seção. Pois o não-todo tampouco se trata de uma salvação, de uma panaceia ou de uma liberação; ele apresenta inúmeras dificuldades, por configurar uma posição que, por um lado, requer "um uso dos semblantes fálicos", mas, por outro, também exige "saber operar com o vazio da castração" (Fuentes, 2012, p. 145).

Como condição para se inventar um saber-fazer com o feminino, é preciso parar de suspirar pelo Um, abandonar a paixão do universal, que por muito tempo mobilizou, por exemplo, o movimento feminista, quando reunido em torno da ilusão d'A mulher. A aspiração pelo universal 
feminino parece surgir da crença masculina numa suposta inferioridade das mulheres em relação aos homens (o que seria uma forma de relação sexual), na medida em que haveria uma desilusão feminina frente à ostentação fálica dos homens como padrão de valor a ser imaginariamente disputado. É como se o conjunto masculino trouxesse a ilusão de constituir um gênero, ao passo que, se o conjunto feminino não se fecha como um todo, as mulheres muitas vezes recaíram numa desilusão pela inexistência de seu gênero, recorrendo à lógica fálica como se ela pudesse servir de alguma garantia para o ser falante, ou como se a universalidade fosse algo capaz de tamponar o furo da linguagem.

Dessa maneira, a estratégia de universalização que encontramos nos gêneros tradicionais pode ser lida como modo de defesa contra o furo estrutural que assombra a própria linguagem, de forma que a neurose, tanto histérica quanto obsessiva, orbita em torno do lado masculino da sexuação, numa tentativa de defender-se do não-todo. Um corolário possível desse empreendimento fracassado é que "o binarismo normativo homem-mulher não existe" (Fuentes, 2012, p. 162), pois, a nosso ver, o arranjo tradicional dos gêneros se situa entre a ilusão masculina e a desilusão feminina; não é possível dar existência aos "dois 'gêneros' como norma" (Fuentes, 2012, p. 162). Assim, essa busca por reunir os sujeitos por meio de uma nomeação dada a partir dos genitais e sedimentada pelo imaginário dos semblantes, como é a proposta dos gêneros, não nos diz o bastante do gozo. Afinal, se o correlato do ideal viril é a crença na existência d'A mulher (Santiago, 2013), esse ideal já aponta para seu próprio fracasso, uma vez que, de um lado, o ser sexuado nunca alcança o Um e, do outro, A mulher não existe.

Nesse sentido, as mulheres, por não se reunirem em torno de Um-niverso, revelam com mais facilidade algo do não-todo fálico, algo que escapa a essa ordenação, já que elas "têm de se haver mais diretamente com a ausência de uma identificação para o feminino" (Fuentes, 2012, p. 189). Se as mulheres estão menos enganadas pelo semblante, fazendo furo no universal, é daí que deriva a nomeação lacaniana que aproxima feminino e não-todo, naquilo que foram as mulheres em análise, na clínica de Freud e de Lacan, que possibilitaram a leitura do não-todo fálico, leitura que tentaremos desdobrar adiante a partir do que nos ensina o contemporâneo. Entretanto, os homens, por muito tempo - e ainda hoje encontramos seus resquícios, nos escombros do ideal viril -, insistiram em universalizar sua falsa totalidade fálica, por terem se deixado fisgar no engodo do órgão. Assim, o ideal viril, no qual se assentam os gêneros tradicionais como tentativa de formar duas classes universais orientadas pelo falo, tem uma implicação na organização do gozo do sujeito. Se o ideal viril declina, isso não é sem efeitos na posição de gozo dos seres sexuados, algo que atestamos pela dita feminização do mundo no contemporâneo. O declínio desse ideal viril tem tido consequências na estruturação dos gêneros, como vemos pela relativa falência atual dos semblantes de gênero tradicionais. Isso levou ao desmantelamento de certo imaginário da sexuação, que tentava dar sentido ao gozo a partir do universal fálico que trabalhamos acima, apresentando, com isso, desdobramentos no real da satisfação pulsional, como desenvolveremos 
adiante. Por ora, trata-se apenas de reter que o declínio do ideal viril o revela como mais afim aos semblantes, por ser ancorado na lógica masculina da sexuação.

A rigor, o que é o ideal viril? É o ideal de fazer Um Todo fálico, pela crença no semblante. Isso implica acreditar nos avatares do falo, naquilo em relação ao que eles fariam suplência ou dariam esteio, uma aparência de garantia, para o órgão. Isso nos permite avançar dizendo que o ideal viril é acreditar também que o semblante fálico vale no real e, por essa crença, tentar fazê-lo valer no real a todo custo, mesmo que desemboque em violência e segregação - o que, na verdade, já atesta seu próprio fracasso. Assim, essa crença no semblante, que localizamos, por exemplo, na ostentação e na parada viril, envolve o desconhecimento de que os avatares fálicos já são uma forma de suplência por velarem um nada, um buraco, que aparece para além do órgão, denunciado em sua insuficiência.

Dessa forma, para que o sujeito masculino suponha que tem o falo, ele precisa sustentar essa crença por um radical desconhecimento de que o que ele tem, isto é, um pênis, não basta. Trata-se de um "não querer saber" do fato de que o que o sujeito tem não é um falo, mas apenas seu representante imaginário. Esse não saber só pode ser conservado pela ilusão de que se pode fazer Um novamente, de que esse sujeito pode fazer Um Todo, porque ele supõe que tem o falo. Mas isso é desmantelado quando o sujeito paga com violência para tentar bancar que isso que ele tem seria o falo, fornecendo a prova última de sua própria impotência. Nesse sentido, quando um homem que tenta se ancorar no universal para abordar uma mulher é rejeitado no jogo amoroso, ele tem de se haver com o fato de que aquilo que ele tem não é suficiente, não esgota o desejo do Outro - e muito menos seu gozo.

Como temos visto, o declínio do ideal viril e seu correlato, a feminização do mundo, têm manifestado precisamente a denúncia dos semblantes protagonizada pelas mulheres, ao apontar que o pênis não é o falo, implicando aí a importância de um luto do ideal viril, uma vez que era em torno desse ideal que a sociedade se organizava. Assim, que o ser falante tenha de fazer o jogo amoroso a partir dos semblantes fálicos já aponta precisamente que isso é algo que vem em suplência ao que não se tem, mas que não se mostrava de maneira clara e distinta para os sujeitos na modernidade. É nesse nível que podemos compreender a afirmação de Lacan (1958-1959/2016, p. 322) de que o grande segredo da psicanálise é o S( ): o Outro sempre terá um ponto faltoso, não totalizável por nenhum significante do desejo que se pretenda último.

\section{Uma sexuação moebiana: encarnações contemporâneas do não-todo}

Conforme Fuentes (2012), as mulheres abriram a via de localização, para a psicanálise, daquilo que é não-todo fálico, por encarnarem algo que resiste à universalização, que faz objeção ao Um-niversal do falo que os homens tentam sustentar. Nisso, elas apontam para algo do nãotodo que não se encontra sob a rubrica do ideal viril, indicando que o resultado da queda desse ideal é precisamente a feminização do mundo, ainda que a crítica ao ideal viril não se confunda 
com a posição feminina na sexuação. Mais do que isso, a crítica ao ideal viril que marca presença com a reivindicação histérica é o que nos permite diferenciar com mais clareza histeria e feminilidade como posições distintas em relação ao gozo (Fuentes, 2012). Se a lógica feminina é o que revela a verdade furada dos semblantes fálicos, trata-se de algo que encontramos, no mundo contemporâneo, não apenas como restrito à experiência das mulheres em seu sentido corrente, mas como experimentado por um grande número de seres falantes, sejam eles mulheres ou homens num sentido corriqueiro. Como se, por assim dizer, o declínio do ideal viril nos tivesse revelado que a sexuação é moebiana, no que todo ser falante é concernido também pelo não-todo, como avesso estrutural do todo fálico (Fuentes, 2012, p. 144).

O que muda, hoje, com a queda do ideal viril é que se revela o caráter moebiano da sexuação, na medida em que todo e não-todo se imbricam como o direito e o avesso do ser sexuado, estando este em maior ou menor articulação com cada dimensão de sua sexuação. Portanto, vivemos os efeitos reais da desconstrução de certo imaginário dos gêneros tradicionais, que, apoiados no ideal viril, tentavam dar um sentido todo fálico ao gozo pela via de uma aparência de complementaridade entre os sexos, empreitada que estava atrelada à norma fálica, conforme discutimos acima. O que acontece, então, é o princípio de um esvaecimento da crença nos semblantes fálicos (afinados com a lógica do todo) devido à escalada do não-todo, como menos enganado pelos semblantes e, até o século XX, majoritariamente encarnado nas mulheres, tal como se apresentaram em análise.

A objeção feminina ao falo vem precisamente do fato de que este não passa de um semblante, sendo mesmo o semblante-mor a organizar o gozo do ser sexuado. É nisso que a organização tradicional dos gêneros girava em torno do falo, fazendo com que sua lógica seja masculina por excelência, da ordem do todo fálico. Mas o contemporâneo tem apontado para o fato, em vias de se desvelar, de que a sexuação, por ser moebiana, faz com que todos os seres falantes mantenham alguma tensão estrutural com o não-todo. Presenciamos, hoje, uma diversidade de encarnações do não-todo no corpo dos seres falantes, sinalizando a decadência de um ideal viril, mesmo que isso não seja sem reações de violência e segregação por parte daqueles que são nostálgicos do ideal todo fálico - e mesmo que nem toda crítica ao ideal viril seja sinônimo de uma posição não-toda.

Nesse sentido, levantamos a hipótese de que a desconstrução dos semblantes tradicionais tem como uma possível consequência a inscrição do não-todo no próprio corpo, para tentar dar contorno à angústia de um gozo Outro, cerzindo o inominável desse estranho gozo que irrompe rebeldemente frente à norma fálica. Isso significa, algumas vezes, jogar com os semblantes tradicionais para mostrar, na carne, que eles não dão conta de totalizar o gozo, não são suficientes para esse tratamento. Talvez seja por isso que atualmente vemos o uso de diversos marcadores de gênero fora de seu lugar normativo como um dos desdobramentos da falência do viril. Forma de apontar a insuficiência dos semblantes e dos lugares que o social tenta determinar, lugares como 
aqueles dos gêneros tradicionais, que não dizem o bastante acerca da confusão que impera no ser sexuado em termos do seu gozo.

Por isso, o ser falante é hoje mais convocado a engendrar invenções próprias para lidar com o que há de mais estranho no seu gozo. Na arte brasileira, têm chamado a atenção as soluções de Liniker, uma jovem cantora transgênero que, num trabalho com o seu corpo, pôde nele constituir o que ela chamou de um "espaço de sobrevivência" (GNT, 2016). Isso a partir de uma quebra radical com os semblantes sexuados tradicionais: "Por que colocar uma calça jeans e uma camiseta e mostrar meu trabalho só com a voz? Meu corpo é um corpo político. Preciso mostrar para as pessoas o que estou passando. 'Este é o Liniker, um cara pode usar um batom, turbante e cantar"' (Morais, 2015).

O reconhecimento do público tem tido grande importância para Liniker se permitir dar um nome a quem ela é: uma "bicha preta" (GNT, 2016). "Agora que estou construindo minha liberdade, se eu não puder ser quem eu sou e vestir o que quero, não vai adiantar de nada" (Morais, 2015), afirma, após ter decidido usar saia e batom pelas ruas. Com relação ao semblante que sustenta, a cantora reitera: "eu tirei o gênero da minha vida. Eu me chamo de a Liniker, o Liniker, apenas Liniker. Exatamente isso que eu tento quebrar com o meu trabalho. Pode ser a cantora Liniker, nascido em Araraquara. Eu não tenho uma fórmula" (Marçal, 2016). Isso está ligado a seu respeito pela singularidade: "Cada um é cada um, cada corpo é uma história" (Morais, 2015). Liniker está atenta ao fato de que a linguagem e os semblantes não bastam; é preciso mais do que isso. Mesmo que esse sujeito não saiba bem o que é que experimenta, ele só sabe que de fato experimenta algo: pode ser que se trate do gozo não-todo, como retratado por Lacan (1972$1973 / 2008$ b, p. 80$)$.

Um gozo indizível, mas que não é sem efeitos no corpo do ser sexuado, cujo tratamento no caso de Liniker, ao embaçar os semblantes tradicionais, é, segundo ela, algo "orgânico", não muito pensado: "eu permito muitas coisas me atravessarem para os processos serem tranquilos" (Marçal, 2016). Trata-se de uma solução que ultrapassa o "tipo ideal do seu sexo", tal como narrado por Lacan (1958/1998a), na medida em que os semblantes de gênero, até certo ponto desacreditados, são recompostos segundo sua própria maneira de tratar os estranhos excessos do gozo. Como relata Liniker, "eu posso ser uma mulher de barba e isso não tem problema. Eu posso ser uma mulher de barba que usa batom. Eu posso ser uma mulher que se vista assim hoje. Esse sou eu. [...] Então, é a minha linguagem" (Marçal, 2016). Assim, esse mais além do falo que Liniker encarna em seu tratamento do não-todo está atrelado a um ultrapassamento do ideal viril, entrelaçado com os arranjos de gênero tradicionais, o que dá margem à sua abertura ao não-todo.

Por causa disso, o não-todo parece implodir a sua nomeação de "feminino", que já era uma tentativa de nomear algo do real indizível (Fuentes, 2012, p. 40); hoje, essa nomeação se mostra relativamente restrita, já que o não-todo tem se prestado a desestabilizar até mesmo as categorias de masculino e feminino, como aprendemos com Liniker, a qual busca inscrever no 
corpo o impasse mesmo da diferença sexual. Essas manifestações têm atestado que as positividades normativas não esgotam a sexualidade, e isso é mostrado por esses sujeitos em seu tratamento do gozo na própria carne de forma deslocalizada, pelo jogo com os semblantes e pela desconstrução dos gêneros tradicionais como consequência do declínio do viril, cujo resultado é a feminização do mundo e, em casos como o de Liniker, a feminização do próprio sujeito.

Num primeiro momento, quando perguntada se se identifica como homem ou mulher, Liniker disse: "Eu realmente não sei. Eu sou bicha, sou preta, mas não sei se eu sou homem, se eu sou mulher, então, tô num processo de... estou sendo o que eu sou, eu sou o que é". o que ressoa como o Deus de Moisés na sarça ardente, que, perguntado sobre quem era, responde a Moisés com a circularidade do "Eu sou o que sou", indicando a ausência de uma resposta do Outro, S( ), e sustentando o enigma do gozo não-todo que a linguagem, sem garantias, não dá conta de esgotar. Isto é, trata-se de reservar um lugar ao inominável. Será possível, ao menos no caso de Liniker, que a resposta ao Che vuoi? seja inscrever no corpo a manutenção da própria pergunta pelo desejo?

Em 2017, ainda assim, a cantora toma uma nova posição. Numa entrevista, ela comenta uma mudança subjetiva, de uma reivindicação como "não-binária" para uma reivindicação como "mulher trans": "Tudo foi um processo. Àquela altura, sentia que não tinha gênero. Não me identificava nem com 'o' e nem com ' $a$ '. Até que um dia, li uma matéria sobre a banda e ao ler 'o cantor' me senti incomodado. A partir de então, entendi que era 'a' Liniker, a cantora". Dessa forma, aos 22 anos, Liniker faz uma passagem do "não-binário" a uma decisão pelo tratamento no feminino, após realizar a leitura de algo do seu gozo que ali estava escrito. Mas ela também afirma que, desde a época de sua não-binariedade, já havia algo lá, em processo, tendo sido importante que ela respeitasse, para isso, o tempo de que precisava para assumir para si mesma sua preferência pelo tratamento com o feminino ("mulher trans"). Em tempos de feminização do mundo, resta-nos acolher, com o devido tempo para compreender, as soluções de cada ser falante para lidar com o indizível do gozo não-todo. $O$ que não é sem consequências para os horizontes da clínica psicanalítica frente à subjetividade de sua época.

\section{Processo de análise e feminização do sujeito}

A partir da denúncia dos gêneros tradicionais como tentativa falhada de fazer existir o Umniversal, apoiada no ser e ter o falo para suprir a relação sexual pela via dos ideais fálicos, sabemos qual foi o duradouro produto dessa estruturação hegemônica, a vigorar por muito tempo: trata-se da colocação, no campo da escória, daqueles que fogem à tentativa de ordenação pelo ideal, no que a proposta tradicional era de uma organização em torno do todo fálico, em que o ser e o ter suspiravam pelo universal. Foi nessa posição de escória que encontramos, ao longo dos séculos - e disso ainda temos as marcas -, gays, lésbicas, bissexuais, transexuais, travestis e demais sujeitos cujos modos de gozo desafiam os semblantes normativos articulados com os ideais 
fálicos. Entretanto, como afirma Lacan, o ideal não passa de um "escravo da sociedade" (Lacan, 1964/1998b p. 846), de modo que, em sua política, orientada pelo não-todo, a psicanálise se posiciona na contramão do ideal, ao dar espaço para os sujeitos desfazerem identificações idealizadas, pautadas no amor genital, na autenticidade, na não-dependência, com vistas a uma pretensa felicidade (Lacan, 1959-1960/2008a, p. 342). Isso na medida em que o campo freudiano não encontra motivo algum para ser guardião do "devaneio burguês" (Lacan, 1959-1960/2008a, p. 355), de modo que é possível pensar mais longe uma análise a partir dessa descrença no ideal. Começaremos por um breve comentário do personagem Tomas, de $A$ insustentável leveza do ser (Kundera, 1984/2008), o qual, mesmo "não tendo uma neurose", por não ser um sujeito real, ainda assim "nos demonstra algo da neurose" (Lacan, 1958-1959/2016, p. 318), de modo que dele nos serviremos inspirados pela maneira como Lacan recorre a Hamlet.

Na obra de Milan Kundera (1984/2008), Tomas é um médico jovem e bem-sucedido que mora sozinho num apartamento em Praga no ano de 1968. Ele se orienta por uma série de insígnias do ideal fálico, sustentando a posição do ter e se organizando a partir do mito viril de ser capaz de gozar de todas as mulheres, o que se atesta pela sua ostentação fálica e pelo modo como ele trata suas várias parceiras sexuais, reduzindo-as a objetos a intercambiáveis. Como contrapartida de sua posição, ele se mostra incapaz de dormir uma noite sequer junto de uma mulher, o que aponta para sua dificuldade em se haver com a questão do amor e revela o lugar da fantasia fetichista que estrutura seu modo de gozo. Trata-se aqui de recuperar essa fantasia fetichista como uma forma de defesa contra a castração do Outro: a ausência de garantias, o ponto da falta de um significante para dizer do desejo do Outro.

Nesse arranjo, a tentativa de escamotear o S( ) parece-nos fazer parte da proposta do ideal viril: este implica reduzir a mulher a um objeto a na via do fetiche, de acordo com a posição masculina do ter, mas para tornar-se a própria exceção que goza de todas as mulheres; e, inversamente, implica também que uma mulher procure no Outro o semblante fálico, para permitir sua posição feminina do ser, fazendo suplência, de seu lado, à ausência de um significante para dizer do universal. No entanto, a chegada de Tereza na vida de Tomas mostra precisamente que não existe relação sexual - tal como vemos, na representação fílmica da obra, no desajeitado momento de sua primeira cena de sexo - , mas que pode haver encontros, modalidades de encontro singulares que tornam supérfluas as tentativas de Tomas de se ancorar nos escombros de seu ideal viril, por permitirem outras formas de suplência, como aquela ancorada no amor.

É certo que Tereza interpela Tomas em busca do falo, mesmo que o que ela ganhe sejam apenas mostras da inexistência da relação sexual, evidenciadas pela radicalidade de um "não saber o que fazer com isso". O que nos interessa, entretanto, nesse tipo de montagem, bastante exemplar da clínica, é o fato de que isso se organizava a partir dos resquícios da crença no Pai, no todo fálico e nos semblantes tradicionais, em que ser e ter eram todo absorvidos na lógica fálica. Com o declínio do ideal viril, denunciado em sua impossibilidade a partir de uma escalada do não- 
todo, podemos pensar outros destinos possíveis ao real do gozo em análise após o desmantelamento desse véu imaginário que recobria a sexuação. Isso na medida em que as fórmulas da sexuação permitem explicitar os limites da lógica fálica, de universalização do ser e do ter, no que essa lógica sofre objeção do não-todo.

Partindo do pressuposto de que a sexuação é de caráter moebiano, por estar sempre comprometida com o furo estrutural do não-todo e, por isso, envolver algo da desordem, sendo apenas recoberta ou ancorada por balizamentos fálicos possíveis, fica evidente que esses balizamentos, antes amarrados ao falo como semblante organizador, estão hoje mais à deriva, no nível das invenções singulares de cada ser falante para lidar com seu gozo, tal como aprendemos com Liniker. Tendo isso em mente, tentaremos articular relações possíveis entre objeto $a_{1} \quad \mathrm{e}$ $\mathrm{S}()$ num percurso analítico masculino marcado pela feminização do sujeito analisante, cujo discurso, como sabemos, vem a ser histericizado - o que, vale lembrar, não significa transformar a condição do sujeito numa neurose histérica, ainda posicionada do lado esquerdo da sexuação.

Esse movimento de histericização específico do processo de análise tem como efeito uma interrogação em relação ao significante fálico que até então ordenou a vida do sujeito. Interrogar, interpelar o é questionar a orientação fálica que vigorou até o presente, dando margem a retomar o Che vuoi? implicado no S( ) e a lidar com a ausência de uma resposta última para o desejo, isto é, convocando a invenção de um saber-fazer com o furo que insiste no Outro. Assim, trata-se, para o analisante, de interpelar o que recobre o $S($ ), na medida em que esse significante fálico se situa como uma resposta ficcional, mas que não se anuncia como tal, ao $\mathrm{S}(\mathrm{)})$. Com isso, o lado feminino interroga essa resposta para que o sujeito possa se haver com o furo, com o enigma do desejo do Outro (Che vuoi?) e com a angústia que o gozo do Outro produz na subjetividade: do Outro como Outro sexo, mas também do Outro que habita o próprio corpo do ser sexuado.

Isso pressupõe a travessia da fantasia, da fantasia fetichista, a fim de sustentar o objeto $a$ como um enigma pelo consentimento com $S($ ), e não mais como uma nostalgia. Na posição masculina da sexuação, o sujeito, barrado, aborda o Outro sexo para encontrar o a que the permita fazer Um, encarnar a exceção, reencontrar um objeto mais-de-gozar que faça um tampão para o sujeito constituir Um Todo fálico, nos moldes do fetiche, que se coloca como uma defesa frente à castração do Outro, S( ). Desse modo, o gozo todo fálico é aquele que acaba por supor o a no corpo do Outro como forma de defesa frente ao furo. No entanto, existe uma assimetria fundamental em jogo na maneira de lidar com a "complementaridade perdida/fantasiada", uma vez que sujeitos femininos e masculinos, na lógica da sexuação, lidam com essa perda abordando o Outro de maneiras diferentes (Carlson, 2010, p. 58).

Diferentemente, o gozo não-todo é aquele que, dividido entre ocupar a posição de objeto $a$ e dirigir-se ao furo do S( ), vem interrogar o significante fálico (Carlson, 2010). Isso significa interpelar o (significante fálico) que está recobrindo $\mathrm{S}(\mathrm{N}$ ), o ponto de falta no Outro, a fim de 
consentir com o estranho ruído de algo no corpo que esfacela o gozo fálico, quando o semblante do falo é destituído de sua posição, fraturado em sua crença. Trata-se, portanto, dos efeitos subjetivos de uma descrença masculina no universal fálico, produzindo uma possível abertura ao não-todo no percurso analítico. Pois, se, na lógica masculina, o objeto a é a forma de recuperar no Outro o gozo perdido, ele é sustentado como uma nostalgia; por sua vez, se, na lógica feminina, o objeto a é mostrado como defesa frente ao furo, ele pode ser sustentado como algo de heteros no próprio gozo do corpo, ou mesmo ser encarado como enigma. Isso nos permite pensar um processo de feminização do sujeito em análise.

Se o a como nostalgia assume a roupagem do objeto mais-de-gozar fetichista, presente do Seminário 16 em diante, ele é retratado de modo bastante diferente do a como objeto causa de desejo, da divisão subjetiva, como concebido no Seminário 10. Neste, não se trata de um tampão para fazer Um, mas daquilo que, no corpo, insiste de maneira enigmática, assombrando o ser falante com um gozo angustiante que não faz todo, que não é totalmente dizível, exigindo um tratamento pela via de uma amarração singular. Num tempo em que as roupagens imaginárias da sexuação e do tipo ideal do sexo dão mostras de seu esgotamento, cumpre ao falasser inventar, por sua conta e risco, um saber-fazer com a parte da satisfação pulsional que não se universaliza, dando algum contorno às estranhas marcas desse gozo que ressoa no corpo de maneira infernal.

\section{Considerações finais}

A partir de nossa leitura do declínio do ideal viril, articulado com a feminização do mundo, pudemos entender os gêneros tradicionais como tentativa de dar existência ao universal de um gozo que fizesse Um, em que ser e ter o falo buscariam suprir a relação sexual pela via dos ideais fálicos, encarnados nas mulheres e nos homens. A psicanálise se construiu, inicialmente, a partir de uma leitura dessas posições, já que estas eram as posições normativas que apareciam na clínica e davam esteio à construção da teoria, servindo a própria teoria como denúncia do malestar produzido pelo ideal. Entretanto, Lacan, ao longo de seu ensino, atento às limitações clínicas dos operadores do ser e ter, foi refinando sua visão sobre o ser sexuado na linguagem, levando-o à construção das tábuas da sexuação, no sentido de situar as limitações da lógica fálica e apontar para seu mais além: o não-todo.

Esse não-todo tem ganhado a cena no mundo contemporâneo, por meio das formas de tratamento desse gozo que denunciam a insuficiência dos semblantes tradicionais ancorados no ideal viril para prestar contas do sexual, algo que pudemos aprender com Liniker. Foi nesse sentido que buscamos pensar o processo de análise como uma passagem do a como nostalgia ao a como enigma, no que isso implica uma descrença na relação sexual, um assentimento com o Outro barrado e uma queda dos ideais. Trata-se, portanto, da importância de fazer o luto do ideal viril, ideal em torno do qual a sociedade por muito tempo se estruturou, de modo que atualmente ainda vivenciamos seus escombros. Mas, no século XXI, o que tem vez é a contingência da invenção de 
algo próprio do sujeito para amarrar o gozo, para dar tratamento àquilo que cada ser sexuado arrastará consigo de singular, resistindo à universalização.

Finalmente, mesmo que "masculino" e "feminino" na sexuação de Lacan não sejam nomeações gratuitas, visto que elas tiveram e ainda têm relação com a maneira com que o ser falante comparece na clínica, podemos pensar numa espécie de implosão da nomenclatura "feminino" por parte do não-todo. Ainda que tenham sido as mulheres, pela via da feminilidade, que compuseram a vanguarda da crítica ao todo fálico na psicanálise ao encarnarem precocemente essa lógica Outra de funcionamento (lógica essa que já era descolada dos semblantes da cultura e da biologia), a nomeação dada por Lacan ao não-todo como "feminino" talvez comece a aparecer como insuficiente frente ao caráter rebelde das manifestações do gozo. Isso a ponto de elas desestabilizarem as próprias categorias de masculino e feminino, apontando para esse campo do inominável que assombra o ser falante, a ser nomeado como gozo não-todo.

\section{Notas:}

${ }^{1}$ Um esboço deste trabalho foi apresentado na XXI Jornada da Escola Brasileira de Psicanálise, seção Minas Gerais, com o tema "O inconsciente e a diferença sexual", realizada nos dias 27 e 28 de outubro de 2017 em Belo Horizonte.

${ }^{2}$ Essas marcas da condição feminina (Fuentes, 2012) se refletem nas teorias freudianas da primazia do falo e do desconhecimento da vagina no inconsciente, além do impasse fundamental do Penisneid na análise das mulheres, o qual é revelador de uma posição subjetiva muito comprometida com o ideal fálico que sustenta a ilusão do Um. Se Freud encontra aí os limites da análise (cf. Análise terminável e interminável), é porque não foi capaz de localizar suficientemente a lógica do feminino enquanto um mais além da castração, restringindo-se ao lado masculino da sexuação.

\section{Referências bibliográficas}

Carlson, S. T. (2010). Transgender Subjectivity and the Logic of Sexual Difference. Differences, 21(2), 46-72. Recuperado de: http://differences.dukejournals.org/content/21/2/46.full.pdf doi: 10.1215/10407391-2010-003.

Fuentes, M. J. S. (2012). As mulheres e seus nomes: Lacan e o feminino. Belo Horizonte: Scriptum. GNT (2016, 07 nov.). Saiba mais sobre Liniker, no quarto episódio de Liberdade de Gênero [vídeo]. Recuperado de: http://gnt.globo.com/programas/liberdade-de-genero/videos/5432515.htm

Kundera, M. (2008). A insustentável leveza do ser. São Paulo: Companhia de Bolso (Trabalho original publicado em 1984).

Lacan, J. (2003a). Os complexos familiares na formação do indivíduo. Outros escritos (pp. 29-90).

Rio de Janeiro: Zahar (Trabalho original publicado em 1938). 
Lacan, J. (1998a). A significação do falo. In: J. Lacan. Escritos (pp. 692-703). Rio de Janeiro: Zahar (Trabalho original publicado em 1958).

Lacan, J. (2016). O Seminário, livro 6: o desejo e sua interpretação. Rio de Janeiro: Zahar (Seminário proferido em 1958-1959).

Lacan, J. (2008a). O Seminário, livro 7: a ética da psicanálise. Rio de Janeiro: Zahar (Seminário proferido em 1959-1960).

Lacan, J. (1998b). Posição do inconsciente. Escritos (pp. 843-864). Rio de Janeiro: Zahar (Trabalho original publicado em 1964).

Lacan, J. (2012). O Seminário, livro 19: ...ou pior. Rio de Janeiro: Zahar (Seminário proferido em 1971-1972).

Lacan, J. (2003b). O aturdito. Outros escritos (pp. 448-497). Rio de Janeiro: Zahar (Trabalho original publicado em 1972).

Lacan, J. (2008b). O Seminário, livro 20: mais, ainda. Rio de Janeiro: Zahar (Seminário proferido em 1972-1973).

Marçal, G. (2016, 11 jun.). 'Posso ser uma mulher de barba que usa batom', afirma Liniker. Estadão. Recuperado de: http://emais.estadao.com.br/noticias/moda-beleza,eu-posso-seruma-mulher-de-barba-que-usa-batom, 10000056719

Miller, J.-A. (2010). El Otro que no existe y sus comités de ética. Buenos Aires: Paidós.

Morais, C. (2015, 13 nov.). Liniker: "sou negro, pobre e gay e tenho potência também". El País. Recuperado de: http://brasil.elpais.com/brasil/2015/11/12/cultura/1447331706_038108.html

Santiago, J. (2013). Corpo de homem. Relatório apresentado no VI ENAPOL, Buenos Aires, Argentina. Recuperado de: http://www.enapol.com/pt/template.php?file=Las-Conversacionesdel-ENAPOL/Cuerpo-de-Hombre/Jesus-Santiago.html

Sinatra, E. (2013). Corpos toxicômanos. Relatório apresentado no VI ENAPOL, Buenos Aires, Argentina. Recuperado de: http://www.enapol.com/pt/template.php?file=Las-Conversacionesdel-ENAPOL/Cuerpos-toxicomanos/Ernesto-Sinatra.html

Teixeira, A. (2007). Do Mesmo ao Outro sexo. A soberania do inútil e outros ensaios de psicanálise e cultura (pp. 33-42). São Paulo: Annablume.

Citacão/Citation: Lima, V. M. \& Vorcaro, M. R. (nov. 2017 a abr. 2018). Ideal feminino e feminização do mundo: uma sexuação moebiana na era do não-todo. Revista aSEPHallus de Orientação Lacaniana, 13(25), 31-46. Disponível em www.isepol.com/asephallus. doi: 10.17852/1809-709x.2019v12n25p31-46

Editor do artigo: Tania Coelho dos Santos.

Recebido/Received: 06/12/2018 / 12/06/2018.

Aceito/Accepted: 10/01/2019 / 01/10/2019.

Copyright: (c) 2018 Associação Núcleo Sephora de Pesquisa sobre o moderno e o contemporâneo. Este é um artigo de livre acesso, que permite uso irrestrito, distribuição e reprodução em qualquer meio, desde que o autor e a fonte sejam citados/This is an open-access article, which permites unrestricted use, distribution, and reproduction in any medium, provided the author and source are credited. 